\title{
Port choice strategies for container carriers in China: a case study of the Bohai Bay Rim port cluster
}

\author{
Jinglei Yang \\ Department of Logistics Management, \\ Nankai University, \\ No. 94, Weijin Road, Nankai District, Tianjin, China \\ Email: jingleiyang@nankai.edu.cn
}

\section{Grace W.Y. Wang*}

Department of Maritime Administration, Texas A\&M University at Galveston, P.O. Box 1675, Galveston, Texas 77553, USA

Email: wangw@tamug.edu

*Corresponding author

\section{Kevin X. Li}

Department of International Logistics, Chung-Ang University, 84 Heukseok-Ro, Dongjak-Gu, Seoul, Korea Email: kxli@cau.ac.kr

\begin{abstract}
The ports of Dalian, Qingdao and Tianjin are the largest ports in the Bohai Bay Rim and as such are among the fastest growing container ports in China. This setting provides an opportunity to analyse the dynamics of competition involved in inter-port clusters. Competition in a port cluster can be examined from the perspective of port choice. To understand the key determinants of carriers' port choice strategies, on-site interviews were conducted in the fall of 2013. Having identified the factors involved, we performed multinomial logit regressions on them. The results indicated that foreign trade routes and destinations, improved design capacity, demand from the hinterland and whether or not there is a rapid boutique line, can sway a carrier's decision towards either a single port strategy or a combined strategy of making two or three stops at the ports of Dalian, Qingdao and Tianjin. As a result of this research, using combined qualitative and quantitative methodologies, a better understanding of the competition, development and governance of not only ports in a regional area, but throughout China itself, has been achieved. This has contributed overall to a better understanding of the dynamics and interrelationships involved between ports in the Bohai Bay Rim.
\end{abstract}

Keywords: Bohai Bay; port cluster; carrier's choices; ship routes; multinomial logit; China.

Reference to this paper should be made as follows: Yang, J., Wang, G.W.Y. and Li, K.X. (2016) 'Port choice strategies for container carriers in China: a case study of the Bohai Bay Rim port cluster', Int. J. Shipping and Transport Logistics, Vol. 8, No. 2, pp.129-152. 
Biographical notes: Jinglei Yang is an Associate Professor in the Department of Logistics Management at Nankai University. Her research interests are port economics and maritime cluster. She is the Vice-Editor of Port Economy, an important journal of port industry in China.

Grace W.Y. Wang is an Associate Professor in Maritime Administration at Texas A\&M University at Galveston. Her research interests are port efficiency, privatisation and incentive mechanism design in terminal concessions. Her selected publications appear in Transportation Research Part E and Maritime Policy and Management. She has been awarded two best paper awards (2012, 2013) and the outstanding paper award selected by Emerald Group Publishing (2014).

Kevin X. Li is a Professor of International Logistics in Department of International Logistics at Chung-Ang University, Korea. He is the co-Editor in Chief of Maritime Policy \& Management: the flagship journal of international shipping and port research.

This paper is a revised and expanded version of a paper entitled 'Competition, cooperation and dynamic governance of Chinese port clusters - the perspective from liner shipping companies' presented at IAME 2014 Conference, Norfolk, VA, USA, 15-18 July 2014.

\section{Introduction}

With a total container throughput that accounted for $82.1 \%$ of China's overall volume in 2013, the Pearl River Delta, Yangtze River Delta and Bohai Bay Rim ports show the fastest growing competition, concentration and port interconnections in China (China Ports Yearbook, 2014). Among the fastest year-to-date growth of China's top ten container ports since January 2013, the Bohai Bay Rim (BBR) ports of Dalian, Qingdao and Tianjin serve to indicate the importance to the region of this fast developing maritime business.

In contrast to the much-studied ports of the Yangtze River Delta (YRD) and Pearl River Delta (PRD), few studies have focused on the BBR ports. The co-existence of multiple ports in that region provides a unique case to analyse inter-port clusters and competitiveness within the region. In this study, we discuss the formation of the cluster in the BBR and the carriers' strategy choices within those ports. Multinomial logit models are adopted and various carriers' strategies are tested.

In the study, we found that, when making a ship voyage to Japan and Korea, a carrier is more likely to choose a two-stop strategy, calling at Tianjin and Dalian, rather than using a one-stop or three-stop strategy. However, a single stop in Qingdao is the prime strategy for carriers considering European and American foreign trade routes. If the carrier focuses on South Asian trade, then a three-stop combination of Tianjin, Dalian and Qingdao is more likely to be selected.

The paper is organised as follows: Section 1 provides an overview of current port clusters in China and a detailed description of major port developments in the BBR. Section 2 reviews the literature on Chinese port choices. Sections 3 and 4 discuss methodology and key factors that influence carriers' behaviour with regard to port choice 
in the BBR. Section 5 reports on the empirical model and the conclusions drawn are highlighted in Section 6.

\subsection{Port cluster development in China}

A port cluster consists of all the economic activities and public (-private) organisations related to the arrival of ships and cargo in ports (de Langen and Visser, 2005). Port clusters may result in agglomeration economies and a strengthened bond of individual and organisational linkage networks. At the same time, though, clusters may intensify internal competition and create possible entry barriers (de Langen, 2004). Effective competition within a cluster may, however, promote cooperation and accelerate innovation and collaboration on new commercial activities in both upstream and downstream industries (Porter, 2000).

Table 1 Total throughput in 2013 of the three major port clusters

\begin{tabular}{lccc}
\hline Port cluster & $\begin{array}{c}\text { Total throughput } \\
\text { (billion tons) }\end{array}$ & Total throughput of main ports (million tons) \\
\hline $\begin{array}{l}\text { Yangtze } \\
\text { River Delta } \\
\text { (YRD) }\end{array}$ & 4.29 & Shanghai: 776 & Ningbo-Zhoushan: 810 \\
& & Suzhou: 454 & Lianyungang: 202 \\
& & Nanjing: 211 & Nantong: 205 \\
Pearl River & Wenzhou: 74 & Shenzhen: 234 \\
Delta* (PRD) & Guangzhou: 472 & Zhongshan: 69 \\
& & Zhuhai: 100 & Shantou: 50 \\
Bohai Bay & Huizhou: 81 & Qingdao: 450 \\
Rim (BBR) & 3.62 & Tianjin: 501 & Tangshan: 446 \\
& & Dalian: 407 & Rizhao: 309 \\
\end{tabular}

Note: *Port of Hong Kong is excluded

Source: Report on China Port Development (2013)

Table 2 Container throughput in 2013 of the three major port clusters

\begin{tabular}{lccc}
\hline Port cluster & $\begin{array}{c}\text { Container throughput } \\
\text { (million TEUs) }\end{array}$ & Total throughput of main ports (million TEUs) \\
\hline $\begin{array}{l}\text { Yangtze } \\
\text { River Delta } \\
\text { (YRD) }\end{array}$ & 69.6 & Shanghai: 33.6 & Ningbo-Zhoushan: 17.3 \\
& & Suzhou: 5.3 & Lianyungang: 5.5 \\
Pearl River & 49.5 & Nanjing: 2.7 & \\
Delta (PRD)* & & Guangzhou: 15.5 & Shenzhen: 23.3 \\
Bohai Bay & 53.1 & Shantou: 1.3 & Zhongshan: 1.3 \\
Rim (BBR) & & Tianjin: 13.0 & Qingdao: 15.5 \\
& & Dalian: 10.0 & Yingkou: 5.3 \\
& & & Rizhao: 2.0 \\
\hline
\end{tabular}

Note: *Port of Hong Kong is excluded

Source: Report on China Port Development (2013) 
Table 1 shows the total throughput in the year 2013 of the three largest port clusters in China. Each cluster has two or more ports in a bounded area showing a geographical concentration of shipping, freight forwarding, nautical services and transportation and logistics services. Companies inside the cluster share information, a common labour pool and both formal and informal communication in port governance and supervision.

\subsection{Latest development of major ports in the BBR}

BBR contains three provinces - Hebei, Shandong and Liaoning - and two municipalities - Tianjin and Beijing. Ports in this region are under various provincial and city governance and jurisdictions. In this region, 60 ports of various sizes are scattered along the 6,584.67 kilometres of coastline (China Ports Yearbook, 2008). Among them, ten 100-million-ton ports are located in this region (as of 2013), with both the largest artificial deep-water harbour (Tianjin) and the largest coal-specific harbour in the world (Qinhuangdao). Taking containers into account, the Port of Tianjin, the Port of Dalian and the Port of Qingdao are the largest comprehensive ports in the BBR. Also, compared to the YRD and PRD, the port cluster in the BBR is unique in its own way:

1 Ports within the BBR are more alike in size. While in the YRD and the PRD the total through put is concentrated in only one or two ports, none of the ports in the BBR have a dominant market share in the region. For example, within the YRD, the throughput volumes of the ports of Shanghai and Ningbo-Zhoushan are ten times more than that of Wenzhou, while the throughput of Tianjin Port is only roughly twice as much as that of the lowest volume port in the BBR.

2 Ports in the region are under various provincial and city governance and jurisdictions. BBR contains three provinces - Hebei, Shandong and Liaoning - and two municipalities - Tianjin and Beijing.

3 Ports within the BBR are more alike in cargo diversification. In this region, there are 12 large ports, the ports of Tianjin, Qingdao, Qinhuangdao, Dalian, Rizhao, Yingkou, Yantai, Huanghua, Tangshan, Jinzhou, Dandong and Weihai.

4 Container terminal business is carried onby the container terminal companies and their holding subsidiaries. Regarding the organisational structures, ports are managed and operated by limited corporation companies, which are also the state (local government)-owned enterprises.

Figure 1 shows the top three ports in the BBR: Dalian, Tianjin and Qingdao, as well as other comparatively small container ports within this region. The figure also shows the total foreign trade volume of the hinterlands. The largest three container ports are located in Liaoning Province, the City of Tianjin and Shandong Province, respectively. Table 3 shows the international trade volumes of container throughput for the ports of Tianjin, Dalian and Qingdao for the years of 2008 to 2013. 
Figure 1 Ports in the BBR port cluster (see online version for colours)

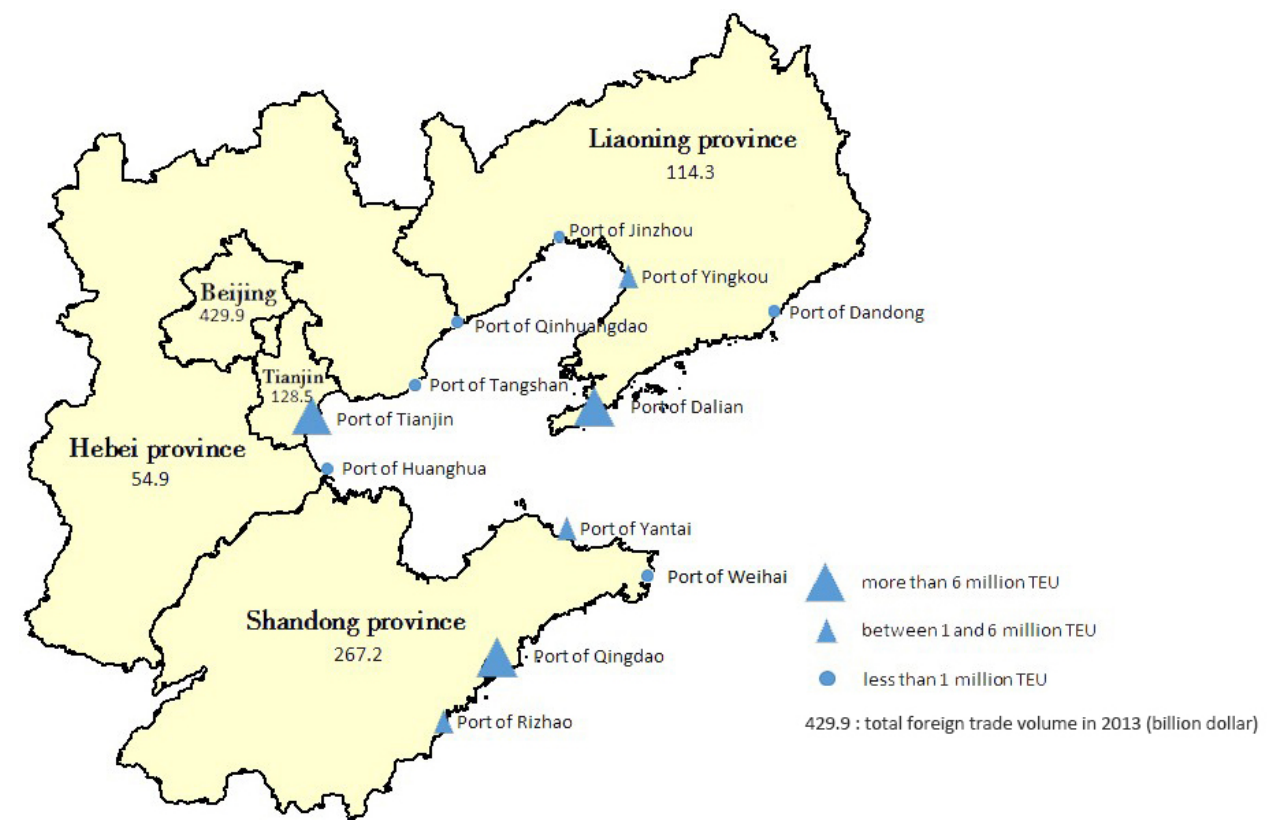

Table 3 Container throughput of three major ports in BBR

\begin{tabular}{lcccccc}
\hline Port & 2008 & 2009 & 2010 & 2011 & 2012 & 2013 \\
\hline Tianjin & 569 & 518 & 549 & 628 & 665 & 698 \\
Dalian & 332 & 310 & 365 & 402 & 405 & 411 \\
Qingdao & 789 & 829 & 961 & 959 & 967 & 995 \\
\hline
\end{tabular}

Note: In ten thousands of TEUs

Source: China Ports Yearbook (2009-2014)

\subsubsection{Port of Dalian ${ }^{1}$}

The Port of Dalian, a natural deep-water harbour, is located in the Southern Liaoning Province on the Yellow Sea. At 470 kilometres distance from Beijing, Dalian is at the entrance to the Bohai Sea and is among the fastest growing ports in Northeast China. In 2012, the Dalian Port Group - the government entity listed on the Hong Kong and Shanghai Stock Exchanges - reported a 13\% increase in total throughputs and a $26 \%$ increase in container volume. Taking into account the shipping route networks within the BBR, domestic container trade volume in the adjacent sea rose by $86.7 \%$, while at the same time international trade increased by $2.3 \%$ (China Ports Yearbook, 2014).

In addition to its existing 99 container routes, the Port of Dalian planned to establish four new train routes, six inland dry ports and 16 medium-sized inland sites to accommodate increased traffic and to be the centre for a railway transport and distribution system [Dalian Port (PDA) Company Limited, 2014]. In addition, this new development, including Taiping Bay, Changxing Island and Dayao Bay, will enhance the utilisation of waterways along the Yellow Sea and the Bohai wing (on-site survey, 2013). 
Regarding its specialisation, Taiping Bay plays a key role in logistics, processing and manufacturing. Changxing Island will be the industrial zone, focusing on petrochemical, oil and liquefied chemicals, timber processing and bulk grain terminals. A joint venture with Odfjell is underway to provide needed terminals and warehousing spaces. Dayao Bay will be the designated area for container shipping. Seven berths to accommodate up to $100,000-200,000$ ton container vessels and three berths to handle up to 70,000-100,000 ton Ro-Ro vessels, will be built on the north shore of the bay (on-site survey, 2013). Total investment in the area is close to 35-40 billion yuan (Chinese Port Year Book, 2014).

\subsubsection{The port of Qingdao}

Around 300 nautical miles from the Port of Incheon, South Korea, the Port of Qingdao is located on the west of the Yellow Sea and at the entrance to Jiaozhou Bay. New Qingdao port contains Dagang, Huangdao, Qianwan and Dongjiakou. Dagang is mainly engaged in grain and break bulk shipping, with four terminals of 18 berth areas. Other than bulk shipping, the new development in the area is to build a cruise terminal that accommodates 225,000-ton cruise ships. Huangdao, a joint venture with Sinopec Qingdao, mainly handles petroleum products, chemical products and liquid bulk cargo. The largest vessel that can be accommodated is a 300,000-ton oil tanker. Qianwan specialises in container and bulk shipping, with the capacity to handle a large vessel up to 18,000 TEUs 3E container ship and 200,000-ton ore bulk carrier. A joint venture with the Qingdao Qianwan Container Terminal Companies Ltd (QQCT) in 2013 facilitates the operation of ten terminals with an extra 36 berth areas (Qingdao Port International Co Ltd, 2014).

In 2013, the port reached a total throughput of 450 million tons in cargo handling and 15.52 million TEUs in container shipping. The port has 153 existing container routes, with 124 international routes (Qingdao Port International Co Ltd, 2014). With the newly developed Dongjiakou area, the port anticipated having 20 more newly developed berth areas with the potential growth of 70 million tons (on-site survey, 2013).

\subsubsection{The port of Tianjin}

Tianjin Port is located at the intersection of the Bohai Rim economic circle and is the gateway to Beijing. It is a key port for international trade in Northern China that connects Northeast Asia to Central and West Asia. With 336 square kilometres of water, 131 square kilometres of land and 159 berths of various kinds, including 102 berths of over 10,000 tons, the Port of Tianjin can, with a high tide, accommodate ships of 300,000 tons. In 2013, the cargo throughput of Tianjin Port was 501 million tons, ranking no. 4 in the world; and the container throughput was 13 million TEUs, ranking no. 10 in the world [Tianjin Port (Group) Co Ltd, 2014].

Tianjin Port consists mainly of the north port, south port and east port, the Harbor Economic Area in the south zone and Nangang Port in the east zone. The north port is mainly engaged in the operation of containers and general cargoes. The south port focuses on dry bulk and liquid bulk cargo. The east port focuses on container terminal operations and maritime services supporting international shipping, logistics, trade and off-shore finance. Heavy equipment manufacturing, new energy, food and light industry are located in the Harbor Economic Area in the south zone. Nangang Port in the east zone 
is a new port area for coal and ore. Recently, in order to enhance the capacity of the logistics network in the hinterland, four marketing centres and 23 inland dry ports were built (Tianjin Port Development Research Center, 2013).

Tianjin Port (Group) Co Ltd, with 40,000 employees, possesses total assets of more than 100 billion yuan over 70 subsidiary enterprises, including two companies listed in the Shanghai and Hong Kong Stock Exchanges. The six container terminal companies under Tianjin Port Co Ltd are Tianjin Port Pacific International Container Terminal, Tianjin Five Continents International Container Terminal, Tianjin Orient Container Terminal, Tianjin Port Alliance International Container Terminal, Tianjin Port Container Terminal and Tianjin Port Euroasia International Container Terminal. According to the annual report of the Tianjin Port Group, it reached 16.626 billion yuan operating revenue and 1.825 billion yuan profit in 2013 (Tianjin Port Co Ltd, 2013).

\section{Literature review}

\subsection{Chinese port clusters}

With its fast growth amid institutional transition, China's port development has garnered much interest from the academic world, with papers analysing privatisation and transport networks in port development (Comtois, 1999), the formation of geographical connections (Lekakou and Vitsounis, 2011), sustainability for regional development (Wang and $\mathrm{Yu}, 1997$ ) and the effect of port reform on port development (Wang et al., 2004). In addition, studies analysing Chinese port clusters are another facet of the research. Each port cluster has drawn a different focus for maritime study. The Pearl River Delta studies have been focused on possible competition and cooperation, the Yangtze River Delta studies have emphasised its spatial development and the BBR studies have been more likely to assess individual port competitiveness.

As one of the most developed port clusters in China, the Pearl River Delta, where Hong Kong, Shenzhen and Guangzhou are located, has become a prime focus of academic studies. Studies of possible competition and cooperation in the region can be found in Wu and Cui (2013) in a port selection model, Liu et al. (2013) for a hinterland with an inland transport network in Shenzhen and Guangzhou, Wang et al. (2012) in a game theory and Song (2002) from a strategic point of view assessing competition and cooperation in the adjacent sea.

Studies of ports in the Yangtze River Delta region, on the other hand, have focused on spatial development changes. Wang et al. (2014) studied the development of China's largest deep-water port, Yangshan Port, using a geographical information system and matlab numerical analysis. Wang and Ducruet (2012) showed the emergence and influence of Yangshan and concluded that local port governance has led to the significant differences in port development in the region. Similarly, Veenstra and Notteboom (2011) presented the formation and development of the Yangtze River port system.

Although the Bohai Bay port cluster is among one of China's three major port clusters, related studies have been very limited in comparison to the Yangtze and Pearl River Delta, due to the diversity and complexity of the Bohai Bay port cluster. Existing researches have focused mostly on the individual port analysis of competitiveness rather than the interconnection between ports. Chen and Wang (2012) identified critical factors affecting the logistic capability for coal supply in the ports of Tianjin and Hebei. 


\subsection{Port choice}

Port choice, which focuses on the decisions of shippers and carriers, is part of customer behaviour research (Brooks, 1984). In the shipping market, especially in liner shipping, customers (users) of port services often include carriers/shipping companies, shippers and freight forwarders (Talley, 2009; Tongzon, 2009). Most literatures have concentrated on the determinants of port users' choices, such as cost- and service-related attributes (Pearson, 1980; Brooks, 1985; Chiu, 1996; Ng, 2006; Tongzon and Sawant, 2007; Veldman et al., 2011; Wu and Cui, 2013), port infrastructure, superstructure and efficiency (Hanelt and Smith, 1987; Tongzon, 2009; Tang et al., 2011), as well as location and the size of the local market (Malchow and Kanafani, 2001, 2004; Tiwari et al., 2003; Kenyon, 1970; Chou, 2007).

A few studies have tried to detect how port selection factors can be valued differently by shippers and freight forwarders (Murphy and Daley, 1994; de Langen, 2007). Some of these literatures have tended to find factors that determine port users' choices in a specific shipping market, such as the trunk and feeder shipping market (Chang et al., 2008) and transhipment market (Lirn et al., 2004; Ng, 2006). As for the geographical scope of the studies, some have taken the perspective of international trade (Tavasszy et al., 2011), while others have tried to explain the motivation behind behaviours from a national (Veldman et al., 2011) or regional (Veldman and Buckmann, 2003) perspective. However, to the best of our knowledge, there is little research discussing port choice behaviour on the basis of port clusters.

From the aspect of methodology of port choice, questionnaires, surveys and interviews have been adopted by most studies and then the various influencing factors were analysed through AHP, factor analysis and other multi-criteria decision technologies. Recently, the logit model, which is used to study the modal split of transportation demand, has been applied to the research of port choice (Malchow, 2001; Tiwari et al., 2003; Tongzon and Sawant, 2007, Veldman et al., 2011; Wu and Cui, 2013). Compared to other methodologies, a logit model can better explain the influencing factors in a revealed preference approach and the critical impacts can also be described more accurately and elaborately (Tongzon and Sawant, 2007). Therefore, the logit model is adopted in our study of port choice behaviour in the BBR.

Almost all literatures on port choice have focused on one given port (or its combination with the onshore/seaborne originations and destinations) as a binary variable. However, those models are unable to explain port call strategies for shipping lines. This paper adds to the value of literature on port choice by testing the combined strategies in a port cluster to analyse whether there is a tendency for a particular port to be preferred, or whether a combined port call strategy dominates. Furthermore, this paper also provides an empirical method for quantifying and evaluating possible competition and port connectivity among ports in a cluster.

\section{Methodology}

\subsection{Qualitative port interviews}

We conducted port interviews to understand the port call and route selection decisions of container shipping companies in the Bohai Bay. The interviewees were: 
- deputy general manager of the Container Department, Tianjin Port (Group) Co Ltd

- $\quad$ vice president, Port Administration of Dalian

- department director, Port and Shipping Administration, Qingdao Municipal Transportation Commission

- marketing manager, Tianjin Five Continents International Container Terminal Co Ltd

- director, Tianjin Shipping Index Institution, Tianjin International Trade and Shipping Service Center ${ }^{2}$

- $\quad$ container operator, Mitsui O.S.K. Lines Tianjin Subsidiary

- deputy director of marketing development, Mitsui O.S.K. Lines Guangzhou subsidiary

- $\quad$ marketing salesman, Department for European Operation, COSCO Shanghai Head Office

- $\quad$ marketing salesman, Department for Japan and Korea Operation, COSCO Shanghai Head Office.

Survey objectives were twofold. First, what factors does the Port Container Terminal Co Ltd believe are important in attracting shipping companies? From the interviews, we concluded that:

1 a strong aggregate supply of final goods from manufacturing in the hinterland leads to an increased demand for shipping services, this being the main reason that attracts shipping companies

2 the geographical location of the port also influences shipping companies' choices; for example, the Port of Tianjin is located on the west of the Bohai Bay, far away from the international mainline, so it has a comparative disadvantage in geographical location

3 given the centralised price control of port dues for container handling on foreign trade, where a guide price for a 20 -foot equivalent unit stevedoring tariff (with a $20 \%$ adjustment being allowed) is stipulated3, service quality such as port turn-around time is considered a critical factor.

Second, for shipping companies who operate and anchor in the Bohai Bay, what are the determinants when choosing between a Port Container Terminal Co. Ltd. or and another terminal? From the interviews, similar conclusions can be drawn from a shipping lines' perspective:

1 a constant large source of supply from the hinterland remains at the top of the list

2 ports located on different trade routes in the Bohai Bay have different advantages relative to foreign and domestic trade, with the choices of port calls for European operations being different from those for Japanese and Korean operations

3 the number of stops made on a trade route also influences the efficient operation of a shipping company. 
Depending on the type of trade, such as short-sea domestic trade or long distance international trade, the number of stops made by the shipping liner companies will be different. Interview questions are available in Appendix.

\subsection{Quantitative multinomial logit regression}

A logit model is commonly used for the study of choices and the decision-making selection. Applications can be found in, for example, transportation (Yang et al., 2013), banking (Caggiano et al., 2014), fast-moving consumer goods and spending (Guadagn and Little, 1983), aviation (Wen et al., 2014), the auto industry (Cecchini, 2001) and the health and pharmaceutical industry (Tarlov and Ware, 1989). In this paper, a multinomial logit model (MNL) by McFadden (1981) is applied to investigate ship owners' port selection decisions in the BBR.

The general formation of the MNL is:

$$
P(Y=j)=\frac{e^{V_{j}}}{1+\sum_{2}^{J} e^{V_{k}}}
$$

where $P$ is the probability that a given carrier's strategy $j$ is selected and $V$ is a factor matrix including firm's internal factors that influence carrier's choice of shipping lines and external factors such as port characteristics and hinterland that affect utility maximisation. Suppose $V_{j}$ is a linear function of internal and external factors, the new formula of MNL can be transformed as:

$$
P\left(Y_{i}=j, \forall j>1\right)=\frac{\exp \left(\alpha_{j}+\beta X_{i j}+g=\gamma_{j} Z_{j}\right)}{1+\sum_{k=2}^{J} \exp \left(\alpha_{k}+\beta X_{i k}+\gamma_{k} Z_{k}\right)}
$$

where $X_{i j}$ denotes the attributes relating to trade direction and characters of ship routes and $Z_{j}$ denotes the attributes relating to ports and their hinterland. $\gamma$ and $\beta$ are the coefficients relating to $Z_{j}$ and $X_{i j}$, respectively. $\alpha$ is the constant. Under the assumption of independence of irrelevant alternatives, MNL is preferred when studying the port choice behaviour of carriers. Data analysis is performed using STATA.

\subsection{The subject of the study - carrier's strategies}

This study focuses on the port choice behaviour in BBR, where the port of Tianjin, Dalian and Qingdao are the top three foreign trade container ports. Hence, in the BBR port cluster, carrier's strategy of port calls can be described in three cases:

1 the carriers make a single stop to complete the shipment (i.e., port of Tianjin, port of Dalian, or port of Qingdao)

2 the carriers make two stops in one voyage to complete the shipment (i.e., the combination of Dalian and Qingdao, Tianjin and Dalian, or Tianjin and Qingdao

3 the carriers stop at three ports in BBR to complete the voyage (i.e., Tianjin, Dalian and Qingdao). 
These three scenarios of carriers' choice represent seven mutually exclusive strategies listed in Figure 2.

Figure 2 Seven port call strategies for ship routes in the BBR

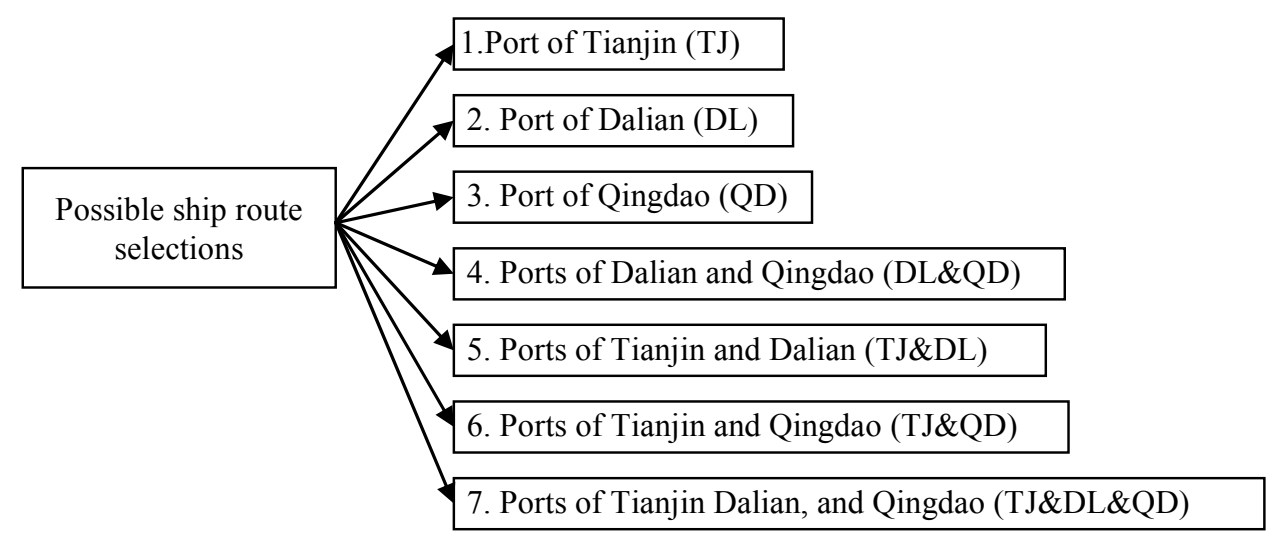

Using the China Ports Yearbook, we obtained information about the shipping routes used by shipping companies from/to/via the container terminals in China during the period 2008-2013. Detailed information was collected on such things as the stops on shipping routes and the shipping companies who operate those lines. 1,721 foreign trade routes operated by more than 80 shipping companies are summarised in Table 4, including 885 one-stop trade routes, 510 two-stop routes and 326 three-stop routes.

Table 4 Port call strategies of shipping lines in the BBR

\begin{tabular}{lcccccccc}
\hline Strategies & & 2008 & 2009 & 2010 & 2011 & 2012 & 2013 & Total \\
\hline Single stop & TJ & 22 & 5 & 24 & 17 & 15 & 11 & 94 \\
& DL & 28 & 18 & 11 & 15 & 25 & 18 & 115 \\
& QD & 111 & 114 & 115 & 107 & 116 & 113 & 676 \\
Two stops & DL\&QD & 19 & 19 & 14 & 12 & 12 & 19 & 95 \\
& TJ\&DL & 53 & 36 & 46 & 52 & 36 & 25 & 248 \\
& TJ\&QD & 31 & 17 & 36 & 32 & 26 & 25 & 167 \\
Three stops & TJ\&DL\&QD & 55 & 37 & 65 & 53 & 62 & 54 & 326 \\
Total & & 319 & 246 & 311 & 288 & 292 & 265 & 1,721 \\
\hline
\end{tabular}

Note: Tianjin (TJ), Dalian (DL) and Qingdao (QD) are the subjects of the study

Source: Derived from the China Ports Yearbook Editor Office (2009-2014)

Detailed information showing trade destinations in 2013 are listed in Table 5, where Qingdao is seen to have the most international routes to trade destinations in USA and Europe, as well as to Japan and South Korea. 
Table 5 Container route network in the BBR in 2013

\begin{tabular}{lcccccc}
\hline Strategy & $\begin{array}{c}\text { Japan and } \\
\text { South Korea }\end{array}$ & $\begin{array}{c}\text { Southeast } \\
\text { Asia }\end{array}$ & Europe & USA & Other & Total \\
\hline TJ & 7 & 1 & 1 & 0 & 2 & 11 \\
DL & 18 & 0 & 0 & 0 & 0 & 18 \\
QD & 29 & 20 & 20 & 28 & 16 & 113 \\
DL\&QD & 9 & 3 & 6 & 1 & 0 & 19 \\
TJ\&DL & 16 & 1 & 3 & 1 & 4 & 25 \\
TJ\&QD & 3 & 4 & 3 & 5 & 10 & 25 \\
TJ\&DL\&QD & 4 & 23 & 8 & 8 & 11 & 54 \\
Total & 86 & 52 & 41 & 43 & 43 & 265 \\
\hline
\end{tabular}

Note: Tianjin (TJ), Dalian (DL) and Qingdao (QD) are the subjects of the study

Source: Derived from the China Ports Yearbook (2014)

\section{Key factors for the empirical study}

Key factors, such as availability of trade routes that serve foreign markets, hinterland cargo demand, port service time, cost of inland transport and port operation efficiency and capacity, were identified through the interviews. Data about ship routes and carrier information were collected through the China Ports Yearbook (China Ports Yearbook Editor Office, 2009-2014) and Report on China Port Development (2008-2013). Data about the hinterland were collected from the National Bureau of Statistics of the People's Republic of China (2009-2014) of the People's Republic of China.

\subsection{Trade routes and destinations}

Because of the implementation of a cabotage policy on coastal transportation in mainland $\mathrm{China}^{4}$, the domestic market for container transportation is relatively isolated from the foreign trade market. Since the transport costs for serving domestic markets are nearly the same for all ports in the BBR, we focus on the container routes delivering foreign trade. Table 6 shows the main trading routes in the BBR. The routes to Japan and South Korea (JAP\&KOR) dominate the market, followed by trade routes directed towards Europe (EU), Southeast Asia (SAE) and America (AME). Foreign trade to Japan and South Korea remained significant throughout the entire timeframe listed, namely 2008-2013.

A high concentration of shipping routes not only affects the amount of time spent in Customs, but also the transportation time involved, such as possible land-side road and warehousing congestion and water-side handling delays. On the other hand, a concentration of traffic and port cluster activities allows for the sharing of common pools of resources and for efficiency improvement. 
Table 6 Trade routes in the BBR

\begin{tabular}{lccccccc}
\hline Routes & 2008 & 2009 & 2010 & 2011 & 2012 & 2013 & Total \\
\hline JAP\&KOR & 115 & 70 & 91 & 96 & 92 & 86 & 550 \\
EU & 48 & 53 & 69 & 61 & 52 & 39 & 322 \\
SAE & 55 & 48 & 55 & 47 & 63 & 52 & 320 \\
AME & 41 & 33 & 54 & 46 & 44 & 43 & 261 \\
Others & 60 & 42 & 45 & 38 & 40 & 43 & 268 \\
\hline
\end{tabular}

Note: The routes included are destinations to Japan and South Korea (JAP\&KOR),

Europe (EU), Southeast Asia (SAE), America (AME) and others (routes to Canada, Australia, etc.)

Source: Derived from the China Ports Yearbook Editor Office (2009-2014)

Because of the nautical distance between a port and a destination, the trade directions could imply a location advantage for each container port in the BBR. For example, since the ports of Dalian and Qingdao have an excellent geographical location with regard to Japan and South Korea's international trade market, the number of shipping lines choosing the Dalian and Qingdao strategy are naturally more than those choosing Tianjin.

\subsection{Rapid boutique lines}

According to our interviews with shipping companies, one of the key factors that influence port choice is delivery time. Given a particular trade direction, certain routes can be sorted into rapid boutique lines, referring to lines that have fewer stops than the average route to complete the voyage. These rapid boutique lines often have greater scheduling reliability, security and safety, but with a relatively higher price than the normal routes. Typically, such shipping lines are pursued by shipping companies having alliances, which mainly cover operating joint services, chartering in vessels, slot sharing and pooled containers (interviews with shipping companies, 2013). Examples below illustrate how we define rapid boutique lines.

For example, there are 550 trade routes to accommodate foreign export and import trade with Japan and Korea. Among this total of 550 routes, the average number of stops to complete the voyage are 5 . For certain routes that have a total of less than five stops, we categorise these lines as rapid boutique lines. Thus, a route starting at Dalian and stopping at Nagoya and Kobe will be listed as a rapid boutique line, since it has less than five stops. However, a route to Japan with seven stops at Tianjin, Dalian, Nagoya, Toyohashi, Tokyo, Yokohama and Tosashimizu is considered as a non-rapid line.

Another example to illustrate the quantification of a rapid boutique line uses foreign trade with USA. There are a total of 261 trade routes in this trade direction and, on average, the entire voyage needs 11 stops to complete. Therefore, routes starting at Qingdao and stopping at Ningbo, Shanghai in China and New York, Norfolk and Savannahin the US will be listed as a rapid boutique line. However, a similar route starting at Qingdao but stopping at Shanghai, Tianjin, Yokohama, Busan, Kobe, Nagoya, Tokyo, Tacoma, Oakland, Savannah, Norfolk, New York and Halifax is listed as a non-rapid line, since the number of stops to complete this voyage are more than the average of 11 . 


\subsection{Foreign sector involvement}

Port industry was among the first groups in China to experience deregulation. This variable is used to capture the percentage of foreign investment in the form of build-operation-transfer and/or joint venture. Interim Provisions on Preferences for the Construction of Ports and Piers with Chinese and Foreign Joint Investment was promulgated by the State Council of the People's Republic of China in 1985. With the emergence of global container terminal operators, foreign investment played a vital role in China's construction of container terminals. During 2005-2011, foreign investment in the ownership structure reached 32.6\% (China Ports Yearbook, 2012). In addition, driven by the need for door-to-door service, shipping companies tend to invest in container terminals within their shipping routes. Therefore, this study focuses on the influence of the ownership structure of container terminals on the carrier's strategy.

The ratio of foreign capital $(F C)$ is used to quantify the percentage of foreign investment. However, in the study period of 2008-2013, the ratios of foreign capital and domestic capital are stable. The average ratio of foreign capital (the regions of Hong Kong, Macao and Taiwan are included) is 0.46 while the average ratio of domestic capital is 0.66 (China Ports Yearbook, 2014).

\subsection{Access to hinterland and aggregate demand}

According to both the interviews and the webpage of the Ports of Tianjin, Qingdao and Dalian, the cities of Tianjin and Beijing, along with Hebei province, are the direct hinterland of the port of Tianjin, while the provinces of Liaoning and Shandong form the hinterland for the ports of Dalian and Qingdao, respectively.

Regional GDP and highway mileage are selected, based on the existing literature, to capture hinterland characteristics. Regional GDP, which represents the size of the local market, is chosen to capture hinterland cargo demand at an aggregate level. Regional GDP of the cities of Tianjin and Beijing, as well as the provinces of Hebei, Liaoning and Shandong, are shown in Table 7.

Table 7 GDP of the hinterland in the BBR (2008-2013) (in 100-million Yuan)

\begin{tabular}{cccccc}
\hline Year & Beijing & Tianjin & Hebei & Liaoning & Shandong \\
\hline 2013 & 19,500 & 14,370 & 28,301 & 27,077 & 54,684 \\
2012 & 17,879 & 12,893 & 26,575 & 24,864 & 50,013 \\
2011 & 16,251 & 11,307 & 24,515 & 22,226 & 45,361 \\
2010 & 14,113 & 9,224 & 20,394 & 18,457 & 39,169 \\
2009 & 12,153 & 7,521 & 17,235 & 15,212 & 33,896 \\
2008 & 11,115 & 6,719 & 16,011 & 13,668 & 30,933 \\
\hline
\end{tabular}

Source: National Bureau of Statistics of the People's Republic of China (2009-2014)

The yearly data of highway mileage from 2008 to 2013 is shown in Table 8 and highway and railway networks in the BBR are shown in Figure 3. Since the hinterland can be reached by efficient road transportation and inland transport, this indicator measures efficient allocation of inland transport and highway capacity to accommodate increasing 
container traffic and/or possible delays in port services due to mismatching of logistics or highway congestion.

Table 8 Highway mileage in BBR (2008-2013)

\begin{tabular}{cccccc}
\hline Year & Beijing & Tianjin & Hebei & Liaoning & Shandong \\
\hline 2013 & 2.16 & 1.55 & 17.40 & 11.01 & 25.28 \\
2012 & 2.15 & 1.54 & 16.30 & 10.56 & 24.46 \\
2011 & 2.13 & 1.52 & 15.70 & 10.40 & 23.32 \\
2010 & 2.11 & 1.48 & 15.43 & 10.15 & 22.99 \\
2009 & 2.08 & 1.43 & 15.21 & 10.11 & 22.67 \\
2008 & 2.03 & 1.21 & 14.95 & 10.11 & 22.07 \\
\hline
\end{tabular}

Note: In ten thousand kilometres

Source: National Bureau of Statistics of the People's Republic of China (2009-2014)

Figure 3 Highway and railway networks in the BBR (see online version for colours)

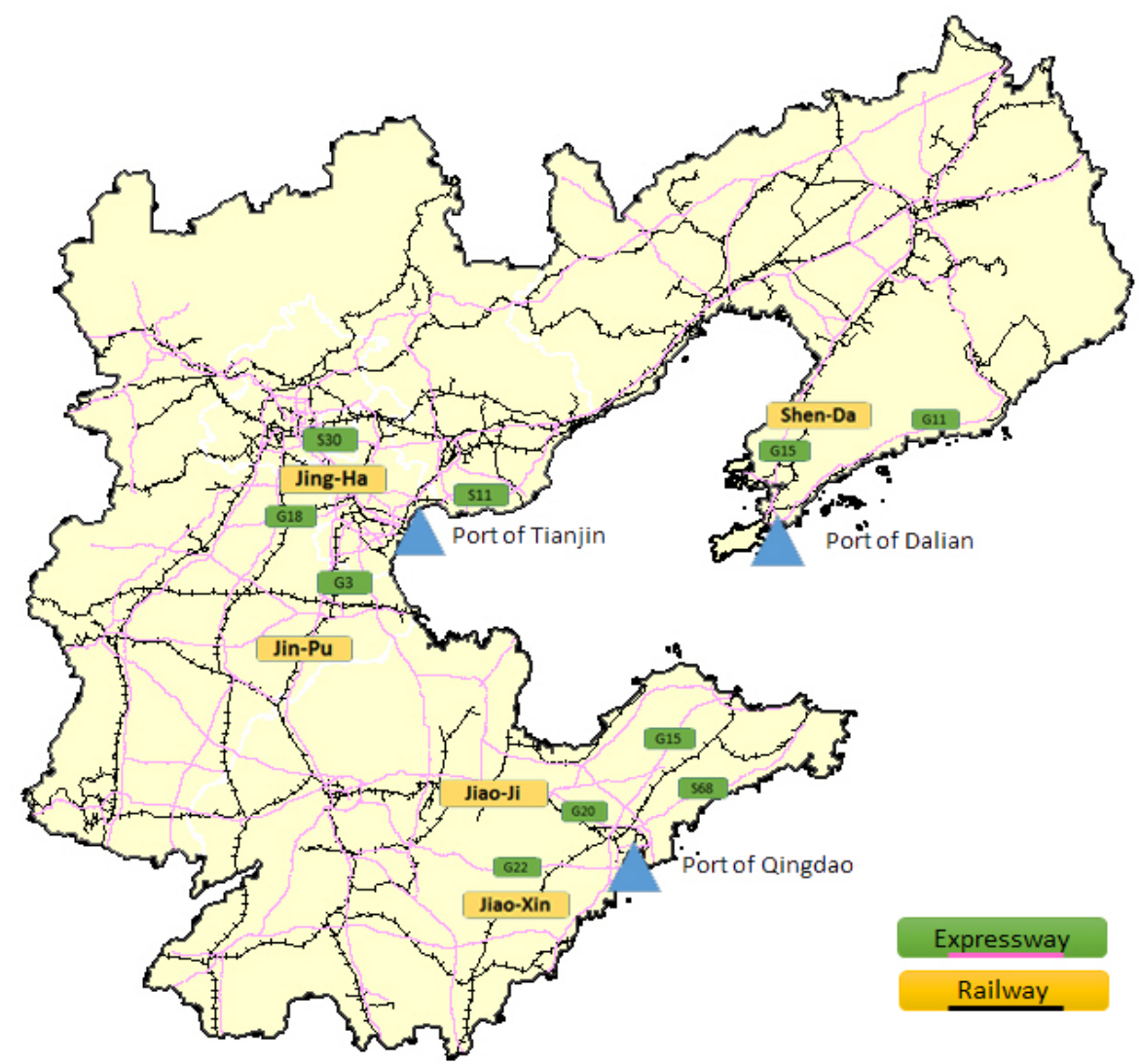

Notes: Yellow tabs refer to railways and green tabs refer to highways,

Government owned highways are listed under ' $G$ ' category and state highways are indicated with an ' $\mathrm{S}$ '

Source: Authors 


\subsection{Capacity}

Given that ship loading and unloading service ratesare at roughly 120 boxes per ship hour among the ports studied (China Ports Yearbook, 2014), the designed maximum capacity (capacity) of container terminals is used to measure terminal services and port activities. Design capacity for container terminals in the ports of Tianjin, Dalian and Qingdao constantly improved during the period 2008-2013. The design capacity of Tianjin Port increased from 9.05 million TEU in 2008 to 11.25 million TEU in 2013. At the same time, capacity grew from 5.05 million TEU and 3.70 million TEU in 2008 , to 8.7 million TEU and 6.15 million TEU in 2013 in the ports of Qingdao and Dalian, respectively.

\section{Empirical results}

Explanatory variables, such as trade routes and destinations, rapid boutique lines, foreign sector investments, designed maximum capacity, highway mileage and regional GDP, are included in the empirical multinomial logit model in order to examine carriers' port choice decisions. A couple of factors do not pass the first-run screening of the MNL. The ownership structures of ports in the BBR, where state-owned capital dominates, are similar to each other, so the ratio of foreign investment is not significant. Similarly, given the smaller volumes handled, the number of coastal lines that serve as feeder lines for main foreign trade routes are not significant enough to influence carriers' port choices. Another factor relating to access to the port hinterland is highway mileage. However, since the extended highway network covers the adjoining areas of Tianjin, Dalian and Qingdao, transport cost rather than the transport infrastructure is considered to be more important.

\subsection{Model 1}

We report on two models. Model 1 (in Table 9), using regional GDP, emphasises the demand for cargo services and hinterland economic development at an aggregate level. Coefficients are explained using the following examples.

We use carrier's strategy TJ\&QD (as highlighted in Table 9) as an example to illustrate the coefficients in the empirical results. The probability of choosing this given strategy can be expressed as

$$
P(J=6)=\frac{e^{-1.96 \text { RapidLines-2.33JAP\&KOR }-0.79 \mathrm{SAE}-1.25 \mathrm{EU}-1.58 \mathrm{AME}+0.39 \mathrm{GDP}}}{1+\sum_{j=1, j \neq \mathrm{TJ} \& \mathrm{QD}}^{7} e^{\alpha_{j}+\beta_{0 j} \text { RapidLines }+\beta_{1 j} \mathrm{JAP} \& \mathrm{KOR}+\beta_{2 j} \mathrm{SAE}+\beta_{3 j} \mathrm{EU}+\beta_{4 j} \mathrm{AME}+\gamma_{j} \mathrm{GDP}}}
$$

Compared to the benchmark strategy of choosing Qingdao, the probability of selecting a two-stop TJ\&QD strategy is positively related to the hinterland's GDP (given the coefficient of GDP is 0.39) and negatively related to the Rapid Lines (given the coefficient of -0.19). When foreign trade is leaning towards Japan and Korea (JAP\&KOR), the multinomial log-odds of TJ\&QD would be expected to decrease by $2.33 \%$. 
Table 9 (Model 1): MNL coefficients of carriers' port choice strategies using GDP

\begin{tabular}{lcccccc}
\hline Strategies & $T J$ & $D L$ & $D L \& Q D$ & $T J \& D L$ & $T J \& Q D$ & $T J \& D L \& Q D$ \\
Variables & & & & & & \\
\hline Rapid lines & $* * * 0.69$ & 0.43 & $* * *-0.73$ & $* * *-0.43$ & -0.19 & $* * *-0.56$ \\
& $(0.3)$ & $(0.4)$ & $(0.2)$ & $(0.2)$ & $(0.2)$ & $(0.1)$ \\
JAP\&KOR & -0.39 & $* * * 3.53$ & $* * * 3.27$ & $* * * 1.66$ & $* * *-2.33$ & $* *-0.61$ \\
& $(0.3)$ & $(1.1)$ & $(0.7)$ & $(0.3)$ & $(0.4)$ & $(0.3)$ \\
SAE & $* * *-1.54$ & 0.51 & $* * * 2.3$ & -0.20 & $* * *-0.79$ & $* * * 1.52$ \\
& $(0.5)$ & $(1.3)$ & $(0.8)$ & $(0.3)$ & $(0.2)$ & $(0.2)$ \\
EU & $* *-0.71$ & -0.58 & 1.21 & 0.22 & $* * *-1.25$ & $* * 0.53$ \\
& $(0.3)$ & $(1.5)$ & $(0.8)$ & $(0.3)$ & $(0.3)$ & $(0.2)$ \\
AME & $* * *-1.73$ & -13.5 & $* * 1.54$ & $* * *-1.41$ & $* * *-1.58$ & -0.05 \\
& $(0.4)$ & $(1.4)$ & $(0.8)$ & $(0.4)$ & $(0.3)$ & $(0.3)$ \\
GDP & $* * * 0.69$ & $* * *-5.76$ & $* * *-1.87$ & $* * *-1.47$ & $* * * 0.39$ & $* * *-0.71$ \\
& $(0.1)$ & $(0.5)$ & $(0.2)$ & $(0.1)$ & $(0.1)$ & $(0.1)$ \\
\multirow{2}{*}{ cons } & $* * *-4.86$ & $* * * 12.34$ & $* * * 2.98$ & $* * * 4.14$ & $* * *-1.96$ & $* * * 1.92$ \\
& $(0.7)$ & $(1.7)$ & $(0.9)$ & $(0.5)$ & $(0.5)$ & $(0.4)$ \\
$\mathrm{N}$ & 94 & 115 & 95 & 248 & 167 & 326 \\
\hline
\end{tabular}

Notes: Total $\mathrm{N}=1721$,

$*, * *$ and $* * *$ indicates significance at the $10 \%, 5 \%$ and $1 \%$ level, respectively, Standard errors are in parentheses,

Six carrier's strategies for port calls are listed across the top of the table, with the single stop of Qingdao being used as the base model,

Single stop strategies include the ports of Tianjin (TJ) and Dalian (DL),

The two stops strategies are the combinations of Dalian and Qingdao (DL\&QD),

Tianjin and Dalian (TJ\&DL), or Tianjin and Qingdao (TJ\&QD)

The three stop strategy is Tianjin, Dalian and Qingdao (TJ\&DL\&QD)

Table 10 Probabilities of strategy used with/without rapid boutique lines

\begin{tabular}{lccccccc}
\hline Strategies & $T J$ & $D L$ & $Q D$ & $D L \& Q D$ & $T J \& D L$ & $T J \& Q D$ & $T J \& D L \& Q D$ \\
$\begin{array}{lcccccc}\text { Variables } \\
\text { JAP\&KOR }\end{array}$ & 0.005 & 0.054 & 0.347 & 0.043 & 0.460 & 0.033 & 0.058 \\
$\begin{array}{l}\text { RapidLine }=1 \\
\text { JAP\&KOR } \\
\text { RapidLine }=0\end{array}$ & 0.014 & 0.003 & 0.244 & 0.181 & 0.469 & 0.013 & 0.075 \\
\hline
\end{tabular}

Notes: Seven mutually exclusive carrier's strategies for port calls are listed across the top of the table,

Single stop strategies include the ports of Tianjin (TJ), Dalian (DL)

and Qingdao (QD),

The two stops strategies are Dalian and Qingdao (DL\&QD), Tianjin and Dalian

(TJ\&DL) and Tianjin and Qingdao (TJ\&QD),

Three stops strategy is Tianjin, Dalian and Qingdao (TJ\&DL\&QD),

Parameters are set as when JAP\&KOR $=1$,

$\mathrm{GDP}=¥ 3.5$ trillion 
Sensitivity analysis is listed in Table 10. Using Japan and Korea trade routes as an example, the likelihood of seven mutually exclusive carrier's strategies can be calculated when we consider the situation with and without the rapid boutique lines. From Table 10, we learn that a carrier is more likely to choose the two-stop strategy of Tianjin and Dalian (TJ\&DL) rather than other one-stop or three-stop strategies to complete the ship voyage to Japan and Korea along rapid boutique lines. However, the two-stop route (TJ\&DL) still outperforms other alternatives when a carrier chooses to use a non-rapid line to complete the foreign trade shipment.

\subsection{Model 2}

Using Qingdao as a benchmark, model 2 (in Table 11), using capacity, captures the maximum scale to which a port can accommodate its vessel services.

Table 11 (Model 2): MNL coefficients of carriers' port choice strategies using capacity

\begin{tabular}{lcccccc}
\hline Strategies & $T J$ & $D L$ & $D L \& Q D$ & $T J \& D L$ & $T J \& Q D$ & $T J \& D L \& Q D$ \\
Variables & & & & & & \\
\hline Rapid lines & $* * 1.22$ & $* * 0.77$ & $* * *-0.65$ & $* *-0.29$ & -0.27 & $* * *-0.53$ \\
& $(0.5)$ & $(0.3)$ & $(0.2)$ & $(0.2)$ & $(0.2)$ & $(0.1)$ \\
JAP\&KOR & 0.89 & $* * * 4.96$ & $* * * 3.44$ & $* * * 1.31$ & $* * *-2.04$ & $* * *-0.86$ \\
& $(0.7)$ & $(1.0)$ & $(0.7)$ & $(0.2)$ & $(0.4)$ & $(0.3)$ \\
SAE & $* *-1.35$ & 1.88 & $* * * 2.65$ & -0.48 & $* * *-0.88$ & $* * * 1.28$ \\
& $(0.8)$ & $(1.2)$ & $(0.8)$ & $(0.3)$ & $(0.3)$ & $(0.2)$ \\
EU & 0.87 & 1.74 & $* * 1.52$ & -0.12 & $* * *-1.29$ & 0.29 \\
AME & $(0.6)$ & $(1.2)$ & $(0.8)$ & $(0.3)$ & $(0.3)$ & $(0.2)$ \\
& $* *-1.36$ & -13.32 & $* * * 1.64$ & $* * *-1.8$ & $* * *-1.86$ & -0.32 \\
Capacity & $* * * 4.94$ & $* * *-0.79$ & $* * *-0.46$ & $* * * 0.44$ & $* * * 2.1$ & $* * * 0.35$ \\
& $(0.7)$ & $(2.3)$ & $(0.8)$ & $(0.4)$ & $(0.3)$ & $(0.3)$ \\
cons & $* * *-47.3$ & -1.04 & -1.06 & $* * *-4.39$ & $* * *-17.46$ & $* * *-3.3$ \\
& $(1.9)$ & $(1.1)$ & $(0.8)$ & $(0.6)$ & $(1.5)$ & $(0.47)$ \\
$\mathrm{N}$ & 94 & 115 & 95 & 248 & 167 & 326 \\
\hline
\end{tabular}

Notes: Total $\mathrm{N}=1721$,

$*, * *$ and $* * *$ indicate significance at the $10 \%, 5 \%$ and $1 \%$ level, respectively,

Standard errors are in parentheses,

Six carrier's strategies for port calls are listed across the top of the table with the single stop of Qingdao being used as the base model,

Single stop strategies include the ports of Tianjin (TJ) and Dalian (DL),

The two stops strategies are the combinations of Dalian and Qingdao (DL\&QD),

Tianjin and Dalian (TJ\&DL), or Tianjin and Qingdao (TJ\&QD),

The three stop strategy is Tianjin, Dalian and Qingdao (TJ\&DL\&QD) 
Table 12 Probabilities of strategy chosen in trade directions using rapid boutique lines

\begin{tabular}{lccccccc}
\hline $\begin{array}{c}\text { Strategies } \\
\text { Variables }\end{array}$ & $T J$ & $D L$ & $Q D$ & $D L \& Q D$ & $T J \& D L$ & $T J \& Q D$ & $T J \& D L \& Q D$ \\
\hline JAP\&KOR & 0.005 & 0.054 & 0.347 & 0.043 & 0.460 & 0.033 & 0.058 \\
SAE & 0.001 & 0.002 & 0.331 & 0.019 & 0.073 & 0.102 & 0.472 \\
EU & 0.007 & 0.003 & 0.478 & 0.009 & 0.152 & 0.098 & 0.254 \\
AME & 0.001 & 0.000 & 0.674 & 0.014 & 0.040 & 0.078 & 0.194 \\
\hline
\end{tabular}

Notes: Seven mutually exclusive carrier's strategies for port calls are listed along the top of the table,

Four mutually exclusive foreign trade directions are listed in the first column, showing Japan and Korea (JAP\&KOR $=1$, others $=0)$, South Asia $(\mathrm{SAE}=1$, others $=0)$, Europe $(\mathrm{EU}=1$, others $=0)$ and America $(\mathrm{AME}=1$, others $=0)$, Other parameters set are: rapid boutique lines $=1$,

Capacity $=8.3$ million TEUs

As shown in column 3 of Table 12, a single stop in Qingdao is the prime strategy for carriers when considering foreign trade routes to Europe and USA. If the carrier is aiming to increase trade with Japan and Korea, then a combined route of Tianjin and Dalian will be ideal. If the carrier focuses on South Asian trade, then a three-stop combination of Tianjin, Dalian and Qingdao is more likely to be selected.

\section{Conclusions}

In the BBR port cluster, dominant port call strategies vary across different trade directions due to oceanic distance and location advantage. For example, some carriers would, out of preference, choose Qingdao, since it offers the nearest routes from Northern China to Europe and USA. To further analyse whether a port can be considered as a load centre port, or as a hub for transhipment loading in a particular trade direction, we establish an assessment index (index of load centre port, ILCP) defined as

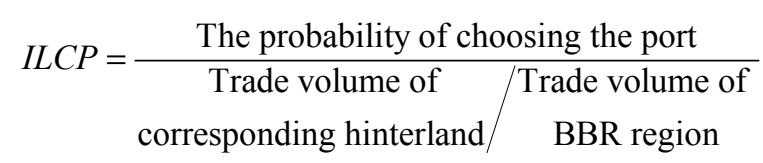

where, in one trade direction, the probability of choosing a port is divided by the proportion of the trade volume of the corresponding port hinterland in the total volume of the BBR region. For foreign trade to Europe and USA, the ILCP of Qingdao is 1.26 and $2.74^{5}$, respectively. When the $I L C P$ is greater than 1 , the port has a tendency to develop into a load centre, since it may attract more cargo from outside its direct hinterland. Otherwise, when the $I L C P$ is less than 1, cargoes may be diverted to other ports. Thus, this port is more likely to become a feeder port in a cluster.

Compared to other single port strategies, Qingdao has the highest tendency to be selected by the shipping lines. As for the combined strategies, the three-stop strategy and the two-stop strategy of Tianjin and Dalianare the prime strategies used by carriers when considering South East Asia and trade with Japan and Korea.

Why would carriers prefer choosing more than one stop in the BBR? According to our interviews, a port-to-port pricing scheme is commonly used on routes within the 
$\mathrm{BBR}$, meaning that the oceanic freight rate for cargo is the same from any main port in a port cluster on one end of the route to the other end. In most cases the shipper is responsible for inland transportation costs to and from the ports, so he will therefore choose the most favourable port to minimise the total transportation costs (interviews with shipping companies, 2013). Due to differences in geographical location, transport infrastructure and transport efficiency, each port in the BBR has its own natural hinterland. Carriers therefore end up choosing one of the combined strategies with two or three stops so as to collect cargo from each port's captive hinterland. Also, it could be concluded from our model that carriers are more inclined to choose one of the combination strategies along with an incremental increase in GDP and expansion of terminal capacity, since most of the coefficients in Tables 9 and 11 are positive. This may imply that a successive increase in GDP and terminal capacity will solidify and equalise the port cluster's hinterland.

This paper presents a study on the development of the BBR port cluster and while researching port choice it takes carriers' strategies into consideration. Carriers' future preferences and port choices can be predicted using the MNL models established. Given the key determinants defined in the literatures on port choice and combining this with interviews with actual practitioners, this study analyses a container carrier's strategies for port choice in the BBR port cluster. Further research is needed in the areas of port governance and policy regulations in an environment that has a constantly changing shipping market structure.

\section{Acknowledgments}

This research was funded by the Research Foundation of Ministry of Education of China (14JZD020).

\section{References}

Brooks, M.R. (1984) 'An alternative theoretical approach to the evaluation of liner shipping (part 1. situational factors)', Maritime Policy and Management, Vol. 11, No. 1, pp.35-43.

Brooks, M.R. (1985) 'An alternative theoretical approach to the evaluation of liner shipping (part 2. choice/criteria)', Maritime Policy and Management, Vol. 12, No. 4, pp.145-155.

Caggiano, G., Calice, P. and Leonida, L. (2014) 'Early warning systems and systemic banking crises in low incomecountries: a multinomial logit approach', Journal of Banking \& Finance, Vol. 47, No. 10, pp.258-269.

Cecchini, L. (2001) 'A logit analysis of the car market', Applied Economics Letters, Vol. 8, No. 3, pp.199-201.

Chang, Y-T., Lee, S-Y. and Tongzon, J.L. (2008) 'Port selection factors by shipping lines: different perspectives between trunk liners and feeder service providers', Marine Policy, Vol. 32, No. 6, pp. $877-885$.

Chen, D. and Wang, G. (2012) 'Coal logistics competency strategies for ports in the Tianjin and Hebei regions around the Bohai Bay in China', Energy Procedia, Vol. 17, No. 2, pp.436-443.

China Port \& Harbours Association Editor Office (2008-2013) Report on China Port Development, The Ports \& Harbours Research Center, China Ports \& Harbours Association, Shanghai, China.

China Ports Yearbook Editor Office (2009-2014) China Ports Yearbook, Chinese Port Magazine Publisher, Shanghai, China (In Chinese). 
Chiu, R.H. (1996) Logistics Performance of Liner Shipping in Taiwan, PhD Dissertation, Department of Maritime Studies and International Transport, University of Wales College of Cardiff, UK.

Chou, C. (2007) 'A fuzzy MCDM method for solving marine transshipment container port selection problems', Applied Mathematics and Computation, Vol. 186, No. 1, pp.435-444.

Comtois, C. (1999) 'The integration of China's port system into global container shipping', Geo Journal, Vol. 48, No. 1, pp.35-42.

Dalian Port (PDA) Company Limited (2014) http://www.portdalian.com/ (In Chinese).

de Langen, P.W. (2004) The Performance of Sea Port Clusters: A Framework to Analyze Cluster Performance and An Application to these A Port Clusters of Durban, Rotterdam and the Lower Mississippi, Rotterdam, ERIM PhD series.

de Langen, P.W. (2007) 'Port competition and selection in contestable hinterlands: the case of Austria', European Journal of Transport and Infrastructure Research, Vol. 7, No. 1, pp.1-14.

de Langen, P.W. and Visser, E.J. (2005) 'Collective action regimes in seaport clusters: the case of the lower Mississippi port cluster', Journal of Transport Geography, Vol. 13, No. 2, pp.173-186.

Guadagn, P.M. and Little, J.D.C. (1983) 'A logit model of brand choice calibrated on scanner data', Marketing Science, Vol. 27, No. 1, pp.29-48.

Hanelt, R.L. and Smith, D.S. (1987) 'The dynamics of west coast container port competition', Journal of the Transportation Research Forum, Vol. 28, No. 1, pp.82-91.

Hebei Provincial Bureau of Statistics (2011) Hebei Yearbook, China Statistical Publishing House, Beijing, China (In Chinese).

Kenyon, J.B. (1970) 'Elements in inter-port competition in the United States', Economic Geography, Vol. 46, No. 1, pp.1-24.

Lekakou, M.B. and Vitsounis, T.K. (2011) 'Market concentration in coastal shipping and limitations to island's accessibility', Research in Transportation Business \& Management, Vol. 2, No. 11, pp.74-82.

Liaoning Yearbook Editor Office (2011) Liaoning Yearbook, China Statistical Publishing House, Beijing, China (In Chinese).

Lirn, T.C., Thanopoulou, H.A. and Beynon, M.J. (2004) 'Beresford AKC. An application of AHP on transshipment port selection: a global perspective', Maritime Economics \& Logistics, Vol. 6, No. 1, pp.70-91.

Liu, L., Wang, K.Y. and Yip, T.Z. (2013) 'Development of a container port system in Pearl River Delta: path to multi-gateway ports', Journal of Transport Geography, Vol. 28, No. 10, pp.30-38.

Malchow, M.B. (2001) An Analysis of Port Selection, Institute of Transportation Studies University of California at Berkeley, Dissertation series UCB-ITS-DS-2001-3.

Malchow, M.B. and Kanafani, A. (2001) 'A disaggregate analysis of factors influencing port selection', Maritime Policy and Management, Vol. 28, No. 3, pp.265-277.

Malchow, M.B. and Kanafani, A. (2004) 'A disaggregate analysis of port selection', Transportation Research Part E, Vol. 40, No. 4, pp.317-337.

McFadden, D.L. (1981) Econometric Models of Probabilistic Choice, pp.198-272, MIT Press, Cambridge, MA.

Murphy, P.R. and Daley, J.M. (1994) 'A comparative analysis of port selection factors', Transportation Journal, Vol. 34, No. 1, pp.15-21.

National Bureau of Statistics of the People's Republic of China (2009-2014) China Statistical Yearbook 2009-2014 (in Chinese) [online] http://data.stats.gov.cn./tjsj/ndsj/.

$\mathrm{Ng}$, K.Y. (2006) 'Assessing the attractiveness of ports in the North European container transshipment market: an agenda for future research in port competition', Maritime Economics and Logistics, Vol. 8, No. 3, pp.234-241. 
Pearson, R. (1980) Container Line Performance and Service Quality, Marine Transport Center, University of Liverpool, Liverpool.

Porter, M.E. (2000) 'Location, competition, and economic development: local clusters in a global economy', Economic Development Quarterly, Vol. 14, No. 1, pp.15-34.

Qingdao Port International Co Ltd (2014) http://www.qdport.com/zjhg.aspx?id=ff4ef8c7-449341c4-9f1a-047025323c44 (In Chinese).

Shandong Yearbook Editor Office (2011) Shandong Yearbook, Shangdong Qi Lu Press Co. Ltd., Shandong, China (In Chinese).

Song, D-W. (2002) 'Regional container port competition and co-operation: the case of Hong Kong and South China', Journal of Transport Geography, Vol. 10, No. 2, pp.99-110.

Talley, W.K. (2009) Port Economics, Routledge, 2 Park Square, Milton Park, Abingdon, Oxon, OX14 4RN.

Tang, L.C., Lam, S.W. and Low, J.M.W. (2011) 'Understanding port choice behavior - a network perspective', Netw Spat Econ, Vol. 11, No. 1, pp.65-82.

Tarlov, J.E. and Ware Jr., J.E. (1989) 'The medical outcomes study', Journal of the American Medical Association, Vol. 262, No. 8, pp.925-930.

Tavasszy, L., Minderhoud, M., Perrin, J-F. and Notteboom, T. (2011) 'A strategic network choice model for global container flows: specification, estimation and application', Journal of Transport Geography, Vol. 19, No. 6, pp.1163-1172.

Tianjin Municipal Bureau of Statistics (2014) Tianjin Statistical Yearbook, China Statistical Press, Tianjin, China (In Chinese).

Tianjin Port (Group) Co Ltd (2014) http://www.ptacn.com about.asp?id=109 (In Chinese).

Tianjin Port Co Ltd (2013) The Abstract of the Annual Report of Tianjin Port Co Ltd, Tianjin Port Development Research Center (In Chinese).

Tianjin Port Development Research Center (2008-2013) Tianjin Port and Maritime Development Report, Tianjin, Tianjin Port Co Ltd, China.

Tiwari, P., Ltoh, H. and Doi, M. (2003) 'Shippers' port and carrier selection behaviour in China: a discrete choice analysis', Maritime Economics \& Logistics, Vol. 5, No. 1, pp.23-39.

Tongzon, J.L. (2009) 'Port choice and freight forwarders', Transport Research Part E, Vol. 45, No. 1, pp.186-195.

Tongzon, J.L. and Sawant, L. (2007) 'Port choice in a competitive environment: from the shipping lines’ perspective', Applied Economics, Vol. 39, No. 4, pp.477-492.

Veenstra, A. and Notteboom, T. (2011) 'The development of the Yangtze River container port system', Journal of Transport Geography, Vol. 19, No. 4, pp.772-781.

Veldman, S. and Buckmann, E. (2003) 'A model on container port competition, an application for the west European container hub ports', Maritime Economics and Logistics, Vol. 5, No. 1, pp.3-22.

Veldman, S., Garcia-Alonso, L. and Vallejo-Pinto, J. (2011) 'Determinants of container port choice in Spain', Maritime Policy \& Management, Vol. 38, No. 5, pp.509-522.

Wang, C. and Ducruet, C. (2012) 'New port development and global city making: emergence of the Shanghai - Yangshan multilayered gateway hub', Journal of Transport Geography, Vol. 25, No. 11, pp.58-69.

Wang, J., Dong, J. and Huang, J. (2014) 'Evolution trend analysis of near shore seabed in Yangshan deep-water port', China. J Coast Conserv, Vol. 18, No. 1, pp.17-25.

Wang, J.J, Ng, A.K-Y. and Olivier, D. (2004) 'Port governance in China: a review of policies in an era of internationalizing port management practices', Transport Policy, Vol. 11, No. 3, pp.237-250.

Wang, K., Ng, A.K-Y., Jasmine, S.L.L. and Fu, X. (2012) 'Cooperation or competition? Factors and conditions affecting regional port governance in South China', Maritime Economics and Logistics, Vol. 14, No. 3, pp.386-408. 
Wang, R. and Yu, G. (1997) 'The open port system in Northeast China', Chinese Geographical Science, Vol. 7, No. 3, pp.270-277.

Wen, C-H., Chen, T-N. and Fu, C. (2014) 'A factor-analytic generalized nested logit model for determining market position of airlines', Transportation Research Part A: Policy and Practice, Vol. 62, No. 4, pp.71-80.

Wu, Y. and Cui, P. (2013) 'A container port choice model for Pearl River Delta Region in South China', Procedia - Social and Behavioral Sciences, Vol. 96, No. 11, pp.1839-1852.

Yang, L., Zheng, G. and Zhu, X. (2013) 'Cross-nested logit model for the joint choice of residential location, travel mode, and departure time', Habitat International, Vol. 38, No. 4, pp.157-166.

\section{Notes}

1 Information and data relating to the ports of Dalian, Qingdao and Tianjin are collected from on-site surveys and from the corresponding website of each port.

2 This institution reports the freight rate of typical shipping lines in Northern China and publishes relevant shipping market analysis weekly.

3 Regulations on collection of port charges of the People's Republic of China (foreign trade Part) (2001).

4 Regulation of the People's Republic of China on International Maritime Transportation, Article 28, Paragraph 2.

5 The data are from the statistical yearbooks of the corresponding regions (Hebei Yearbook, 2011; Liaoning Yearbook, 2011; Shandong Yearbook, 2011; Tianjin Statistical Yearbook, 2011).

6 http://www.portdalian.com/.

\section{Appendix}

\section{Port interview questions}

The interviews mainly evaluate factors influencing the decision-making process when choosing a port, from the perspective of both container terminal and carrier.

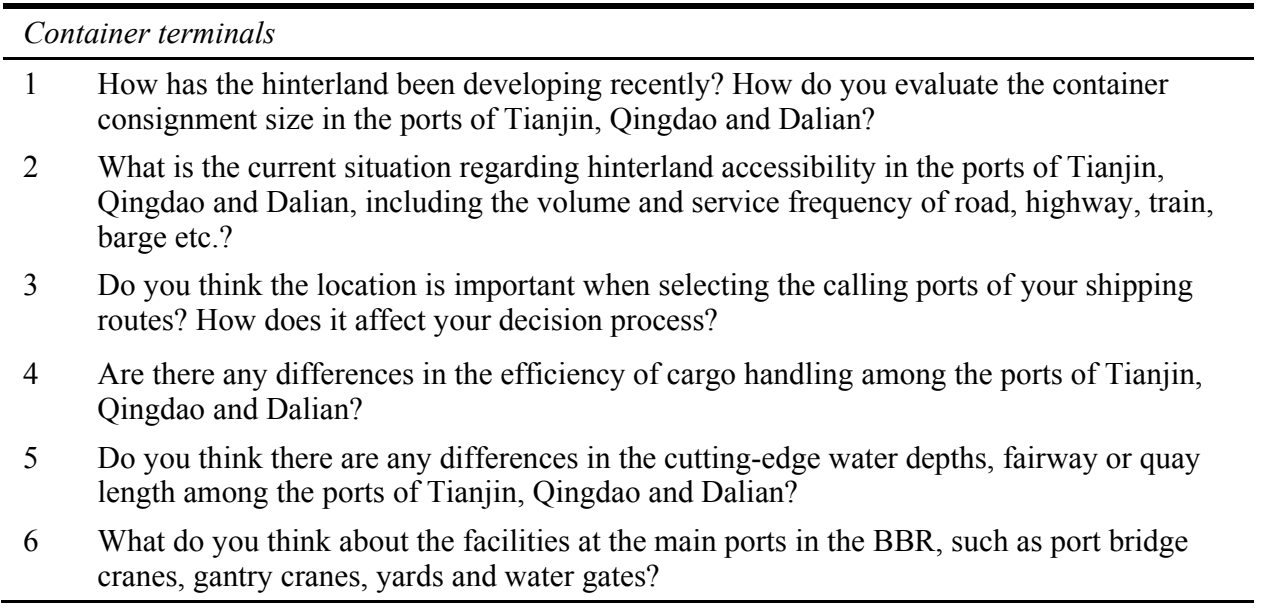




\section{Port interview questions (continued)}

The interviews mainly evaluate factors influencing the decision-making process when choosing a port, from the perspective of both container terminal and carrier.

Container terminals

7 How do you assess the ownership structure of the ports of Tianjin, Qingdao and Dalian? For example, does foreign sector involvement have any impact on its operational efficiency and affect the shipping liners' preference?

8 Is there any significant difference with regard to government support or the policy environment among the ports of Tianjin, Qingdao and Dalian?

9 Are there any differences in ports' charges, even though the Ministry of Transport of the People's Republic of China has certain regulations and charging standards regarding the services? How do port prices affect a shipping company's port choice decisions?

10 As a container terminal company, what other factors do you believe are important in attracting shipping companies?

Carriers

1 How do you evaluate the aggregate trade demand in the ports of Tianjin, Qingdao and Dalian?

2 Among those three ports, are the differences in hinterland accessibility, such as by road, highway, train, barge and other transport facilities, affecting port choice behaviour?

3 Are there any differences in calling port selection strategies among different trade directions?

4 Is the port-to-port pricing strategy commonly used in routes within the BBR? Are there any differences in pricing policies among the shipping routes which call at Tianjin, Qingdao and Dalian ports?

5 How does the number of stops affect the port choice strategy? What difference does it make when selecting calling ports for the rapid lines and normal lines?

6 How do you think transactions like mergers, acquisitions and/or alliances may affect the port choice process in order to achieve a lower unit cost?

7 Is ship size one of the important factors when choosing calling ports in the BBR?

8 What is your comment on the port charges and service quality of the ports of Tianjin, Qingdao and Dalian? Do you think this is an important issue?

9 What other impacts are there in the infrastructures, such as cutting-edge water depth, quay length and fairway, which could influence port choice decisions? Which of the infrastructures is the most important factor that influences your decision-making?

10 As a shipping company, are there any other determinants in choosing a port or a container terminal? 